Volume: 12 Issue: 1 Year: 2015

\title{
Biomedical ethical evaluation of Turkish newspaper articles on face transplants ${ }^{1}$
}

\author{
Zehra Göçmen Baykara² \\ Sevil Güler Demir ${ }^{3}$ \\ Sevilay Erden ${ }^{4}$
}

\begin{abstract}
The use of face transplants has become possible in Turkey and the world in recent years. Face transplants are not just an exchange of tissue between the donor and the recipient and are social and ethical issues concerning the health care institutions, health care team and the public. The interest and criticism of the health care professionals, institutions, public and media regarding the transplants have led to various ethical problems.

This study aimed to perform an biomedical ethical evaluation of the newspaper articles on face transplant cases. The study used retrospective, descriptive, qualitative and quantitative data. The study scope included news from the three highest-selling newspapers published in Turkey with Internet archives that were accessible online. An evaluation form developed by the investigators after a literature review was used for evaluation of the articles.

According to the study data, we found that the articles focused mostly on benefits such as the positive changes in the individual patient and the relatives, the decreased or eliminated psychological pain of the patient, the importance of organ transplants, and increased trust in the health care team. The most common violations in the articles were regarding protection of privacy and confidentiality by announcing the names of the donor and recipient, and sharing the treatment process.

In conclusion, the necessary training must be provided to ensure health care staff, health care institutions and journalists possess the necessary ethical sensitivity and act according to professional ethical principles.
\end{abstract}

Keywords: Face transplantation; biomedical ethics; principles of ethics.

\footnotetext{
${ }^{1}$ Oral Presentation, VII. Plastic Reconstructive and Aesthetic Surgical Nursing Congress. Izmir, Turkey. 2012.

${ }^{2}$ RN, Ph.D., Instructor, Gazi University, Faculty of Health Sciences, Department of Nursing, gocmenzehra@yahoo.com

${ }^{3}$ RN, Ph.D., Instructor, Gazi University, Faculty of Health Sciences, Department of Nursing, sevilgulerdemir@yahoo.com

${ }^{4}$ RN, Ph.D., Assistant Professor, Çukurova University, Health College of Adana, Department of Nursing, sevilaygil@yahoo.com
} 
Göçmen Baykara, Z., Güler Demir, S., \& Erden, S. (2015). Biomedical ethical evaluation of Turkish newspaper articles on face transplants. International Journal of Human Sciences, 12(1), 427-442. doi: 10.14687/ijhs.v12i1.3076

\section{Introduction}

Scientific and technological advances have led to significant developments in health care procedures, methods and techniques. One of these developments is tissue and organ transfer (Elçioğlu, 2003). Tissue and organ transfer involves the replacement of a diseased tissue or organ that has failed and is threatening the person's life (Oğuz, Tepe, Büken \& Kucur, 2005).

Organ transplants started in the mid-20th century. The first renal transplant was in 1947 and the first heart transplant in 1967. The first successful heart transplant in Turkey was in 1975. Organs such as the liver, heart, kidney, pancreas and small intestines and also tissues such as bone marrow, cornea, and cardiac valves are currently successfully translated both in Turkey and the world (Akış, Katırc1, Uludağ, Küçükkılıç, Gürbüz, Türker , et al; Türkiye Organ ve Doku Bilgi Sistemi Nakil İstatistikleri, 2013).

Another type of transplant that is becoming popular in the world is a composite tissue transplantation. Face transplantations have been used in Turkey and the world in recent years. Face transplantation is a surgical procedure used for patients with a face deformity that cannot be repaired with conventional methods and who suffer greatly because of it (Ağaoğlu, Külahçı \& Siemionow, 2006). The first face transplantation in the world was on a 38-year-old woman in France in 2005 after she was attacked by a dog and suffered nose, lip and cheek trauma. Face transplants were then performed in China in 2006 and in the USA between 2007 and 2009 (Edgar, 2009; Pomahac, Nowinski, Diaz-Siso, Bueno, Talbot, et al., 2011). A total of 10 patients have received a face transplant between 2009 and January 2011 (Barret, Serracanta, Collado, Garrido, Salamero, Pont, et al., 2011). The number of face transplant surgeries performed following tumors or trauma is constantly increasing globally.

Double arm transplantation from a cadaver in 2010 and uterus transplantation were performed successfully in Turkey in 2011. Health care professionals performed the first face transplantation and double arm and single leg transplantation surgeries on two different patients from the same donor in 2012. However, the transplanted leg was later removed for medical reasons. Another university hospital performed face transplantation on one patient and double arm and double leg transplantation on another patient in the same year. The patient with the leg transplantation died 3 days after the procedure. A total of 6 face transplantation procedures have been performed in three different university hospitals in Turkey since January 2012 (Türkiye Biyoetik Derneği, 2012; Unal, 2013; Anadolu Ajans1, 2013; Akkır1, 2013). The interest in face transplantation is increasing in both the society and the health care system and it is not just a tissue and organ exchange between the donor and recipient. It is also a social and ethical issue concerning the health care institutions, health care team and the public. The interest and criticism of the health 
Göçmen Baykara, Z., Güler Demir, S., \& Erden, S. (2015). Biomedical ethical evaluation of Turkish newspaper articles on face transplants. International Journal of Human Sciences, 12(1), 427-442. doi: 10.14687/ijhs.v12i1.3076

care professionals, institutions, public and the media regarding the transplants have led to various ethical problems. The main ethical problems/queries related to face transplants are whether the patient's expectations from the procedure are fully met, the competition between health care professionals, whether the transplant patient receives full and accurate information before the procedure, whether the patients are used as research subjects, the persons benefiting, the lack of long-term results after the procedure, the risk of life-threatening complications developing, etc (Ağaoğlu, Külahçı \& Siemionow, 2006; Siemionow, Bramstedt \& Kodish, 2007; Vercler, 2010). We believe that these problems and queries will continue to be valid in various dimensions (medical, societal, occupational, financial, etc.) with the increase in face transplantation procedures and the longer survival afterwards. Therefore all health care professionals, have important ethical responsibilities. Nurses defend the patient and are constantly with them, giving them an ethical role to protect patient rights (ICN, 2012; THD, 2009).

Besides such health care professionals, the media also has important responsibilities as it informs the public about these transplants. The effect of the media on the public is clear. The media has been very interested in the face transplantations performed in Turkey and has informed the public of the patients about to undergo the procedure, their family, the managers of the relevant institutions, and the transplant team (Unal, 2013; Anadolu Ajans1, 2013; Akkır1, 2013).

Our observation as health care professionals is that the media has sometimes guided the public without a full understanding or comprehension of the issue. We believe that the news media will influence how the society sees these procedures and therefore the treatment and care process of the donor, recipient and their families.

\section{Purpose}

This study was conducted for the purpose of investigating reports in newspapers published on face transplants, considered to be the "new initiative in the field of medicine" in Turkey and the world from the perspective of health professionals and in terms of biomedical ethical principles.

\section{Materials and Methods}

\section{The place and time of the study}

The study scope included news from the three highest-selling newspapers published in Turkey with Internet archives that were accessible online. The study was performed between January 2012 (the month face transplantation was performed in Turkey) and August 2012 (when the data were reviewed). 


\section{Population and sample selection}

All articles in the archives of the newspapers between January 1 and August 15, 2012 were screened with the "face transplantation" keywords and the 609 articles found made up the study universe. The study sample included the 159 articles that had not been recirculated on the donors and recipients of face transplantation procedures from our country.

\section{Type of study}

This was a retrospective and descriptive study with quantitative and qualitative data.

\section{Data collection}

An evaluation form developed by the investigators after a literature review was used for evaluation of the articles (ICN, 2012; THD, 2009). The evaluation form consisted of two parts. The first part was prepared using the Patient Rights Regulation and the World Physicians Association Patient Rights Declaration (T.C. Sağlık Bakanlığ1, 1998; Türk Tabipler Birliği Merkez Konseyi, 2009). This part includes 32 questions to evaluate the articles in relation to ethical principles (benefiting / not harming: 22 questions; respecting confidentiality and protecting privacy: 5 questions; respecting autonomy / respecting the individual: 3 questions, fairness: 2 questions). The second part of the form contained 4 open-ended questions on ethical principles.

\section{Limitations of the study}

In this study, newspaper articles on face transplants was analysed in the scope of principles of biomedical ethics. Moreover principles of media ethics were not addressed in detail.

\section{Evaluation of data}

Frequency and percentages were used for the statistical evaluation of quantitative study data. The qualitative data evaluated the articles for biomedical ethical principles and classified them according to the five themes mentioned above. The data were analyzed by the investigators using the thematic analysis method according to this classification. The reports were analyzed from a healthcare professional perspective according to basic biomedical ethical principles. A code was used to prevent naming the donors and recipients of the face transplants and the newspapers when using quotes from the articles. 
Göçmen Baykara, Z., Güler Demir, S., \& Erden, S. (2015). Biomedical ethical evaluation of Turkish newspaper articles on face transplants. International Journal of Human Sciences, 12(1), 427-442. doi: 10.14687/ijhs.v12i1.3076

\section{Results}

Figure 1: Distribution of newspaper articles related to face transplantation by months $(\mathrm{N}=159)$.

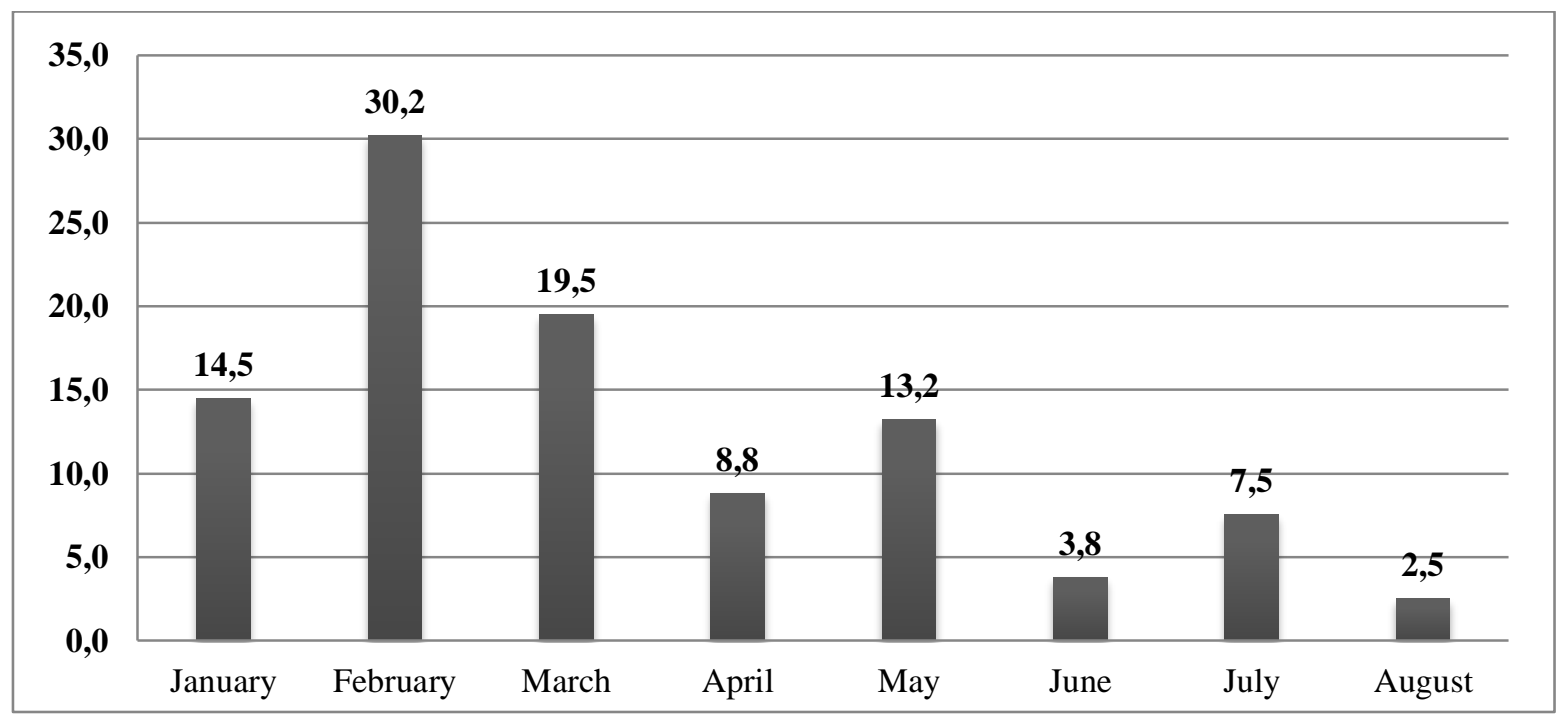

There have been a total of 4 face transplantation procedures in Turkey in 2012, three on males and one on a female. The first face transplantation was from a 45-year-old donor to a 19year-old patient on January 21, 2012 and the 4th procedure was from a 19-year-old donor to a 35year-old patient on May 15, 2012. Three of the procedures were full and one partial face transplantation. Of the articles evaluated in the study, 30.2\% had been published in February, 19.5\% in March and 14.5\% in January (Figure 1). Articles on face transplantation appeared most commonly in February in the newspapers $(30.2 \%)$ and decreased as time passed after the procedure.

The main emphasis in the newspaper articles was on the benefits. These benefits were usually the beneficial changes in the patient's and family's life and the decrease in or elimination of psychological suffering regarding the individual and family, emphasizing the importance of organ transplantation as regards the community and increased trust in the health care team as regards the health care system. The most common ethical violations were naming the donor and recipient, sharing the treatment process and not protecting privacy or confidentiality (Table 1). 
Göçmen Baykara, Z., Güler Demir, S., \& Erden, S. (2015). Biomedical ethical evaluation of Turkish newspaper articles on face transplants. International Journal of Human Sciences, 12(1), 427-442. doi: 10.14687/ijhs.v12i1.3076

Table 1: Distribution of ethical violations in newspaper articles on face transplantation $(\mathrm{N}=159)$.

\begin{tabular}{|c|c|c|c|c|}
\hline \multirow{2}{*}{$\begin{array}{l}\text { ETHICAL PRINCIPLES } \\
\text { Providing The Benefit, Do No Harm }\end{array}$} & \multicolumn{2}{|c|}{$\begin{array}{l}\text { Number of } \\
\text { articles* }\end{array}$} & \multicolumn{2}{|c|}{$\begin{array}{l}\text { Number of } \\
\text { Articles with } \\
\text { Ethical } \\
\text { Violations* }\end{array}$} \\
\hline \multirow{2}{*}{\multicolumn{5}{|c|}{ Providing the benefit, do no harm to the individual }} \\
\hline & & & & \\
\hline Positive changes in the life of the patient and family & 75 & 47.2 & 8 & 5.0 \\
\hline $\begin{array}{l}\text { Decrease in / elimination of the patient's psychological } \\
\text { suffering }\end{array}$ & 34 & 21.4 & 9 & 5.7 \\
\hline Care in presenting health services & 28 & 17.6 & 8 & 5.0 \\
\hline $\begin{array}{l}\text { Appropriate measures to prevent patient harm after } \\
\text { transplantation }\end{array}$ & 24 & 15.1 & 5 & 3.1 \\
\hline $\begin{array}{l}\text { Using the potential of science and technology for the } \\
\text { patient }\end{array}$ & 19 & 11.9 & 1 & 0.6 \\
\hline $\begin{array}{l}\text { The patient not being harmed because of lack of care or } \\
\text { experience, or negligence }\end{array}$ & 17 & 10.7 & 5 & 3.1 \\
\hline Performing face transplantation on suitable patients only & 15 & 9.4 & 5 & 3.1 \\
\hline Positive benefit on the donor's family & 14 & 8.8 & - & - \\
\hline Continuity of health care & 13 & 8.2 & - & - \\
\hline Negative affect on donor's family & 8 & 5.0 & 7 & 4.4 \\
\hline Negative changes in the life of the patient and family & 7 & 4.4 & 6 & 3.8 \\
\hline $\begin{array}{l}\text { Decrease in / elimination of the patient's physical } \\
\text { suffering }\end{array}$ & 3 & 1.9 & - & - \\
\hline \multicolumn{5}{|l|}{ Providing the benefit, do no harm to the community } \\
\hline Awareness of the importance of organ transplantation & 32 & 20.1 & - & - \\
\hline An increase in the number of donors & 19 & 11.9 & - & - \\
\hline An increase in the number of recipients & 9 & 5.7 & - & - \\
\hline \multicolumn{5}{|l|}{ Providing the benefit, do no harm to the health care system } \\
\hline Increased trust in the health care team & 35 & 22.0 & 10 & 6.3 \\
\hline Increased respect for health care professionals & 29 & 18.2 & - & - \\
\hline $\begin{array}{l}\text { Sharing of knowledge and skills by health care } \\
\text { professionals }\end{array}$ & 24 & 15.1 & 2 & 1.3 \\
\hline Development of the health care system & 19 & 11.9 & - & - \\
\hline Increased demand for health care institutions & 16 & 10.1 & 2 & 1.3 \\
\hline Scientific competition between scientists & 7 & 4.4 & 2 & 1.3 \\
\hline Increased motivation of health care professionals & 2 & 1.3 & - & \\
\hline \multicolumn{5}{|l|}{ Respect for Autonomy and the Individual } \\
\hline $\begin{array}{l}\text { The patient's participation in decisions regarding the } \\
\text { transplantation, treatment and care process and deciding } \\
\text { freely }\end{array}$ & 15 & 9.4 & 4 & 2.5 \\
\hline $\begin{array}{l}\text { The patient being provided sufficient information on the } \\
\text { transplantation, treatment and care process }\end{array}$ & 7 & 4.4 & - & - \\
\hline $\begin{array}{l}\text { Protecting the patient's dignity and avoiding actions that } \\
\text { will humiliate the patient }\end{array}$ & 7 & 4.4 & 1 & 0.6 \\
\hline \multicolumn{5}{|l|}{ Protecting Privacy and Respecting Confidentiality } \\
\hline Naming donors & 99 & 62.3 & 94 & 59.1 \\
\hline Naming recipients & 75 & 47.2 & 70 & 44.0 \\
\hline Sharing the treatment process of the recipient & 46 & 28.9 & 46 & 28.9 \\
\hline
\end{tabular}


Göçmen Baykara, Z., Güler Demir, S., \& Erden, S. (2015). Biomedical ethical evaluation of Turkish newspaper articles on face transplants. International Journal of Human Sciences, 12(1), 427-442. doi: 10.14687/ijhs.v12i1.3076

Keeping patient information confidential

Respecting and protecting patient confidentiality

\section{Justice}

A justice distribution of limited resources (the face) according to patient requirements

Every person receiving the proper health care service without discrimination

$N$ was folded. The percentages were determined according to the number of articles reviewed

$\begin{array}{rrrr}27 & 17.0 & 24 & 15.1 \\ 24 & 15.1 & 13 & 8.2 \\ & & & \\ 12 & 7.5 & 3 & 1.9 \\ 9 & 5.7 & 1 & 0.6\end{array}$
6

\section{The Principle of Providing Benefits and Doing No Harm}

The most common issues in the published articles were the beneficial aspects of face transplantation and providing more benefit for the individuals, the public and the health care system in parallel (Table 1).

Some examples of the statements regarding face transplantation benefits for the person are as follows:

"I am very happy. It is almost as life is starting now. Everything has changed. Of course physicians play a role in this. My mustache and beard are starting to appear, I have shaved three times. My face is better every day. The surgical material in my eye will be removed in two months and there will be no problems." (Newspaper-3)

"P-1 said he had previously had an appearance that children and others who saw bim for the first time were afraid of and added now people want to approach me, to talk to me. My new face attracts a lot of attention. I like bearing I am handsome from others." (Newspaper-2)

"P-1 who underwent the first face transplantation surgery in Turkey has started work at ... Hospital as a contracted worker." (Newspaper-2)

The newspapers also mention the benefit of face transplantation to the community in addition to the individual. Some examples of the statements regarding the benefit of face transplantation for the community are as follows:

"I wish everyone donated... One donation saves many lives. I am going to donate my organs too." (Newspaper-3)

"The ...... Association members donated their bodies to be used as cadavers by medical students so that mankind will benefit and their organs and tissues to others, after being influenced by the recent transplantations." (Newspaper-1)

"Organ donation is wonderful. We need to make our society aware of this. There are many people who need the procedure, are in dire straits and are waiting in the list. We need to be sensitive as a society." (Newspaper-1)

"The world is talking about Turkey. Media from many countries, from the USA to the Far East are interested in the triple organ and face transplantation performed at ... Hospital." (Newspaper-1) 
Göçmen Baykara, Z., Güler Demir, S., \& Erden, S. (2015). Biomedical ethical evaluation of Turkish newspaper articles on face transplants. International Journal of Human Sciences, 12(1), 427-442. doi: 10.14687/ijhs.v12i1.3076

The articles also state that the face transplantation have increased the trust in and demand for the health care system in Turkey. Some examples of the expressions regarding the benefits of face transplantation to the health care system are as follows:

"The successful organ and face transplantations by Turkish physicians are firmly in the country and world agenda. Citizens of many countries started to apply to Turkish centers for transplantation after closely monitoring the surgeries" (Newspaper-3).

"There is increased trust in Turkish physicians and an increased number of organ donors." (Newspaper-3)

"It was said that approximately 125 persons had applied since the surgery and 35 had been found suitable for face transplantation after the examinations and observations and they had been placed in the institute registry.” (Newspaper-2).

"The donations increased 4 fold. The consecutive firsts at the... Hospital increased interest in organ transplantation.” (Newspaper-2).

Although we mostly found articles emphasizing benefits in newspapers in our study, we also saw that there were articles on the harm to patients' relatives and the health care system. An article emphasizing the loss of trust in the healthcare team is provided below:

“... Patient P-3... underwent a face transplantation without indication although the Council did not think it was appropriate." (Newspaper-3)

There was private information on the donor family in some articles while some others mentioned that the donor family could be affected negatively. An example is the article below:

"... The family of P-4, father of 6 children, who became depressed due to family reasons and committed suicide by jumping under a train 12 days ago, decided to donate all the organs of P-4 after brain death was observed." (Newspaper-2)

The benefits of face transplantation in multiple aspects were emphasized in the articles. However, it is seen that there is little mention of the indefinite character of the quantity and duration of these benefits and the risks of the transplantation.

\section{The Principle of Respect for Autonomy}

We found that $9.4 \%$ of the articles evaluated in the study mentioned participation and making free decisions by the patients regarding the transplantation, treatment and care process and $4.4 \%$ mentioned the importance of providing adequate information, protecting the dignity of the patient and avoiding humiliating behavior during this process. Some articles on the respect for autonomy principle were as follows: 
Göçmen Baykara, Z., Güler Demir, S., \& Erden, S. (2015). Biomedical ethical evaluation of Turkish newspaper articles on face transplants. International Journal of Human Sciences, 12(1), 427-442. doi: 10.14687/ijhs.v12i1.3076

"P-6's photographs had been shared after obtaining permission from bim and the family following the intense interest and requests received from the media." (Newspaper-3)

"P-7 said he knew the risks of the surgery and had been provided relevant information, but still wanted to undergo face transplantation.” (Newspaper-1)

"...Dr.... We had to inform you to the extent that we obtained permission from the patient from the beginning of the surgery and with the permission of the family and patient afterwards. It's a very new thing. The public needs to know about this. The public accepts it to the extent it is informed about it and it has now accepted this." (Newspaper-1)

As can be seen from the above examples, the articles generally mention that the information has been shared while respecting autonomy.

\section{The Principle of Respect for Privacy and Protecting Confidentiality}

We found that the principles of respecting privacy and protecting confidentiality was violated in the published articles. The most common violations of this principle were related to 'naming the recipient' (59.1\%), 'naming the donor' (44.0\%) and 'sharing the treatment process of the recipient' $(28.9 \%)$ (Table 1).

We present an example of an article emphasizing the importance of respect for privacy and protecting confidentiality and saying that these were taken into account below:

"We had the photographs and images of the face of P-1 that had made a living hell and required face transplantation, from the start. However, we did not use them so as not to sadden him, his family and the millions who were following these news with excitement.... "(Newspaper-1)

"Although the law has limited the requirement for confidentiality to the physician keeping the identity of the donor and recipient secret, it is also necessary not to explain the identity of the donor and recipient when organ and tissue transplantation is performed from the dead..." (Newspaper-3)

We did come across article examples where the principles of respecting confidentiality and protecting privacy were violated:

"19-year-old P-1 who underwent face transplantation at ... In Turkey and is getting ready to be discharged does not go for a walk at the hospital garden without putting gel on his hair.” (Newspaper-1)

"P-1 talked to me about what he experienced before and after the transplantation and what he dreamed of for the future. P-1 said he wanted to go to his military service first now. He said he would first wait to complete one year and then evaluate the ... employment offers." (Newspaper-1).

The following are examples of articles sharing the recipient's treatment process:

"..... P-1 walked for about 15 minutes with his brother and hospital security and said "I obtained permission from my physicians to walk so that I would not have a weight problem and I could move my legs. I went 
Göçmen Baykara, Z., Güler Demir, S., \& Erden, S. (2015). Biomedical ethical evaluation of Turkish newspaper articles on face transplants. International Journal of Human Sciences, 12(1), 427-442. doi: 10.14687/ijhs.v12i1.3076

outside voluntarily after 34 days. It's a beautiful day but I always had to make do with the sunlight coming in through the window. My physicians permitted me to walk when I wanted." (Newspaper-1).

"... has been living with his new face for approximately three months. He stands in front of the mirror for one bour every day. He performs facial movements five times a day. He blows a balloon and blows on the flute. It is expected that it will take him six months to use facial expressions and talk properly. However, he has already started to use facial expressions a month after surgery..." (Newspaper-1).

The newspapers had many articles on the names of the face transplantation donor and recipient, the experience before the face transplantation and the treatment process after the procedure. Their photographs also appeared on the newspapers as they were the first to undergo face transplantation in Turkey.

\section{The Principle of Justice}

We found that the least covered issue in the articles was related to the justice principle. The news was generally on the right of everyone to receive the proper healthcare service without discrimination (5.7\%) and sharing limited resources (the face) fairly according to patient requirements $(7.5 \%)$. Some examples of these articles were as follows:

"Dr. ... said face transplantations would be performed according to a scoring system after a while and added "As with other organ transplantations, it will be performed on those who need it most, deserve it most and have been waiting for it most. For example, the criteria could be that the patient cannot close his eyes, cannot eat and drink, cannot breathe, cannot go among others, and all these will be scored. A score will be determined accordingly." (Newspaper-3)

"The patient will be scored out of 100 according to the problems in the new system and the person most deserving the transplant will get it." (Newspaper-3)

"Approximately 125 persons had applied since the surgery and 35 had been found suitable for face transplantation after the examinations and observations and they had been placed in the institute registry." (Newspaper-2)

However, some of the articles stated that composite tissues that are a limited resource had been given to unsuitable patients. Some examples are below.

"We found that ... Hospital had performed extremity transplantation although P-6 had no indication in a way that violates the Composite Tissue Transplantation Center Regulations and Current Indication Guide while patient P-7 underwent a face transplantation without indication although not found suitable by the Council.”(Newspaper-1)

"It was alleged that ... Hospital arranged a report with false statements so that it could with the face transplantation race."(Newspaper-1) 
Göçmen Baykara, Z., Güler Demir, S., \& Erden, S. (2015). Biomedical ethical evaluation of Turkish newspaper articles on face transplants. International Journal of Human Sciences, 12(1), 427-442. doi: 10.14687/ijhs.v12i1.3076

We found some articles stating face transplantations had been performed on unsuitable patients, wasting many limited resources (tissue, work, time, material, money, manpower, etc.), in the name of fairness. This harms the patient, health care professionals and health care institutions. It is not only a violation of justice but also of other ethical principles.

\section{Discussion}

In this section, reports published regarding face transplants have been discussed from a healthcare professional perspective within the context of basic biomedical ethical principles.

\section{Benefiting - Do Not Harm}

The most emphasis of the articles was on the "benefiting - do not harm" principle. The benefiting principle was evaluated in various aspects for the individual, society, country and health care professionals.

Newspapers had many articles on the benefits of face transplantation for the individual and the families. The patients said they felt happy, were more beautiful / handsome, they could look in the mirror, they could get married, they could find work and had a face accepted by society. Health care professionals concentrated on the benefit of the patients. Face transplantation surgery is performed for the patient's benefit, just like other surgeries. However, it must not be forgotten that this benefit is not absolute. The individuals have to undergo intense drug treatment and a care and monitoring process after the procedure. The long-term results of these transplantations and the immunosuppressive drugs used afterwards are not fully known (A ğaoğlu, Külahçı \& Siemionow, 2006). Face transplantations also carry life-threatening risks such as rejection, infection, drug toxicity and malignancy (Barret, Serracanta, Collado, Garrido, Salamero, Pont, et al.,2011). It is therefore not possible to be definite about the amount and duration of the benefit. Within this context, healthcare professionals primarily have an important role in correctly informing the public. Journalists have the ethical responsibility of "exploring and reporting the truth, minimizing damage" (Medya Derneği, 2011).

Some patients said they were happy that others got to know them and that the media was interested in them. Face transplantation procedures were performed in Turkey for the first time so the patients became a person of interest for the media at the early postoperative stages. The individual "who no one looked at before" became known by many persons and institutions and received a lot of attention that he was not used to. One patient said to a newspaper "Children and those who saw me for the first time used to be scared of me previously... I attract a lot of interest with my new face. I like hearing I am handsome from others." This interest of the public and the media in the individual will gradually fade and the person will go back to normal life with his relatives. It is therefore better to 
Göçmen Baykara, Z., Güler Demir, S., \& Erden, S. (2015). Biomedical ethical evaluation of Turkish newspaper articles on face transplants. International Journal of Human Sciences, 12(1), 427-442. doi: 10.14687/ijhs.v12i1.3076

evaluate the life and feeling, the difficulties and changes, and the benefits/harms of surgery for the person undergoing the face transplantation in the long term. The "exaggerated" benefit of the face transplantation in the articles can lead to the public being misguided in the long term. The public may demand medically inappropriate transplants because of these exaggerated articles. This may cause new ethical problems for health care professionals. Health professionals should pay attention during their interviews with journalists due to the newspaper articles appeal and influence to a wide audience.

We found that the articles on face transplantation were not only on the effect on the transplanted person and his/her family but also on the public. We mainly came across articles emphasizing the importance of organ transplants. In one article, the patient invited everyone to donating their organs by saying "Everyone should donate their organs. I am going to donate my organs too. I am also going to convince my family members one by one to get them to donate." According to the Waiting List date of the Ministry of Health on August 31, 2013 there are a total of 28.175 persons waiting for organ donation (Türkiye Organ ve Doku Bilgi Sistemi Güncel Bekleme Listesi, 2013). The number of organ donors in Turkey is 10.839 (Türkiye Organ ve Doku Bilgi Sistemi Donör İstatistikleri, 2013). Although there were 1044 brain deaths in Turkey in 2013, the family of only 248 permitted organ transplantation (Türkiye Organ ve Doku Bilgi Sistemi Beyin Ölümü İstatistikleri, 2013). Considering the inadequacy of organ donors, we feel it is important to increase sensitivity regarding organ donation with the articles on face transplantation. According to the Ministry of Health statistics from the same date, the rate of face and scalp donation (4054 donations) within the context of composite tissue donations (32.830 donations) is similar to the rate of other composite tissue donations (Türkiye Organ ve Doku Bağıșı Bilgi Sistemi Kompozit Organ İstatistikleri, 2013). This is an indicator of the public's interest in face and scalp transplantation.

The articles also mention the benefits of face transplantation for our country. One article stated "The successful organ and face transplantations by Turkish physicians are firmly in the country and world agenda. Citizens of many countries started to apply to Turkish centers for transplantation after closely monitoring the surgeries". It is quite important for the world press to cover face transplantation news in Turkey to communicate the medical developments in our country.

The study also found articles stating the transplantations had increased trust in health care professionals in our country. Having the newspapers cover successful transplantations is important in increasing trust for health care professionals and the institutions performing the transplantations. However, the news also covered unsuccessful transplantations, publicly blaming and criticising the healthcare institutions and the professionals. It is an ethical principle for journalists to "provide accurate information for the public" (Medya Derneği, 2011), and for health care professionals to act in 
Göçmen Baykara, Z., Güler Demir, S., \& Erden, S. (2015). Biomedical ethical evaluation of Turkish newspaper articles on face transplants. International Journal of Human Sciences, 12(1), 427-442. doi: 10.14687/ijhs.v12i1.3076

the benefit of the patient. It is necessary for the printed media and healthcare professionals to be extremely careful in informing society.

The "competition" and "ambition" to be the first in transplantation can cause health care professionals to make mistakes. The focus on success by health care professionals and institutions can prevent accurate evaluation of patient benefit.

\section{The Principle of Respect for Autonomy and Protecting Privacy}

We found articles stating most patients had been informed by their physicians preoperatively regarding respect for autonomy. One patient said he was informed about the procedure and added "The physicians said it was risky surgery. I said "I am not living now anyway, I don't feel anything. I am going to undergo this procedure, I am not scared." According to the Patient Rights Regulation of Turkey and the Human Rights Bioethical Medical Agreement, patient should be informed about the risk of future surgery, alternative treatment methods and postoperative expectations. Any surgery that will risk the patient's life should be avoided (TC Sağlık Bakanlığı, 1998; Biyoloji Tıbbın Uygulanması Bakımından İnsan Hakları ve İnsan Haysiyetinin Korunması Sözleşmesi, 2004). However, the patients said they wanted to undergo the surgery in any case. This must be evaluated carefully by the surgical team. The patients can demand face transplantation surgery "putting their life at risk". The psychological pressure of their face defect can prevent them from making rational decisions. The health care team has to evaluate the patient who will undergo the face transplantation both from the physical and psychosocial point of view and make sure he/she is making an autonomous decision. In addition, they should also make accurate guidance to patients regarding their briefing in front of media. That is considerably important for both avoid sharing of the issues regarding patients' post tranplatation life, which they could be uncorfortable and do not misdirection of society. We found that the most commonly violated principle in the articles was that of respecting confidentiality and privacy. The names of all the face transplantation donors and recipients were provided in the papers and the postoperative images, previous life and plans for the future were shared with the media. It is said that the patients had given their permission in the articles. This situation is important problem for biomedical ethics even though it has not carry any ethical problems for journalism.

Although it is said that the information is provided after the patient's consent, the Patient Rights Regulations of Turkey says 'the information obtained through provision of health care services cannot be divulged in any way unless permitted by law" (T.C. Sağlık Bakanlığı, 2012). Article 4 of the Statute on Medical Deontology also states "The physician and dentist cannot disclose the secrets learned through his/her occupation or craft unless there is a legal requirement. 
Göçmen Baykara, Z., Güler Demir, S., \& Erden, S. (2015). Biomedical ethical evaluation of Turkish newspaper articles on face transplants. International Journal of Human Sciences, 12(1), 427-442. doi: 10.14687/ijhs.v12i1.3076

The person's identity cannot be disclosed in cases presented in medical meetings or published" (T.C. Sağlık Bakanlığı Türkiye Kamu Hastaneleri Kurumu, 1960). It is not ethically appropriate to share most of the information of individuals who have undergone a face transplantation nationally. The Turkish Bioethics Associations has stated that articles on face transplantation "did not conform to the rule of protecting patient confidentiality, medical data secrecy and the privacy of the patient" (Türkiye Biyoetik Derneği, 2012). Sensational journalism started to become prominent in the media, especially after the $19^{\text {th }}$ century (Erdoğan, 2006). The media is forced to report news under the pressure of many factors (economic, political etc). Thus, the media is not always able to primarily consider reporting news according to ethical principles. It is the ethical responsibility of physicians, nurses and other health care professionals to protect the patient's identity and data to prevent unforeseen harm to the patient and relatives.

\section{The Principle of Justice}

We also came across some articles emphasizing justice during our study. The articles mentioned how the patients waiting for transplantation would be selected and who would be given priority. We believe that the successful face transplantation procedures performed in our country will increase the relevant demand. The most important issue is how realistic the demands are. There are medical criteria for face transplantation (Kompozit Doku Nakli Merkezleri Yönergesi, 2011; Kompozit Doku Nakli Endikasyon Listesi, 2011). However, these criteria may not always be absolute or definite for the patient or the physicians. However, successful transplants will increase the number of demands and expand the limits currently defined by the criteria. These limits are not definite lines and can create gray areas. The recent developments and requests may cause the gray area to widen and the line to become more indefinite. Some newspaper articles state that individuals have undergone face transplantation without an indication and that the patient has therefore been harmed. It is therefore possible for inappropriate transplantations to be performed if health care professionals/ institutions / health care policies do not define proper measures in the face of rapidly increasing demand. All health care policy makers and especially health care professionals, and the public and the media need to be sensitive regarding the limits.

Another problem as regards the justice principle is that these surgeries require time, labor, patients, material and facilities. These surgeries also require many health care professionals to cooperate and many resources to be used at the same time. Some of the articles on face transplantations also mentioned other transplantations and that hundreds of units of blood and blood products and many drugs had been used for a patient that died a few days after transplantation and that a large team spent a lot of time on this patient. The important point 
Göçmen Baykara, Z., Güler Demir, S., \& Erden, S. (2015). Biomedical ethical evaluation of Turkish newspaper articles on face transplants. International Journal of Human Sciences, 12(1), 427-442. doi: 10.14687/ijhs.v12i1.3076

regarding fairness is using limited resources for an individual that definitely needs them. It is therefore quite important to share limited resources fairly, avoid unnecessary treatment and case, and using limited resources in a way that provides the most benefit. It can therefore be possible to protect ethical principles in the best way. Plastic surgeons are responsible for evaluating the benefit level of the patient and the expectations of the patient and relatives (Wong, Camp, Camp \& Gupta, 2010; Sterodimas, Radwanski \& Pitanguy, 2011). The most important responsibility belongs to the physician, nurse and other health care professionals.

Physicians, nurses and other health care professionals must be careful to protect patient rights before, during and after any procedure on the patients.

\section{Conclusions and recommendations}

In conclusion, we found that ethical principles had been violated in the articles on face transplantation, especially regarding personal information and the protection of confidentiality. The media has significant power in informing and increasing the awareness of society. The use of this power by the media and healthcare professionals in accordance with professional ethical principles and in a correct manner is considered to be for the benefit of society. It is taking attention that in the newspaper articles biomedical ethical principles are infringed much than the ethical principles of media. In this context, it is recommended that organization of training activities for expecially health professionals and journalists to gain professional ethical sensitivity and display ethical behaviours.

\section{References}

Ağaoğlu G., Külahçı Y., Siemionow M. (2006). Yüz transplantasyonu: dünü bugünü ve yarını. Türk Plasitik Rekontriktif Cerrabi Dergisi, 14(1), 8-13.

Akış, M., Katırcı, E., Uludağ, H.Y., Küçükkılıç B., Gürbüz T., Türker Y., et al. (2008). Süleyman Demirel Üniversitesi personelinin organ-doku bağışı ve nakli hakkındaki bilgi ve tutumları. Süleyman Demirel Üniversitesi Thp Fakültesi Dergisi, 15(4), 28-33.

Akkırı, E. Beşinci yüz nakli hastası kamera karşısında. Hürriyet Gazetesi. http://hurarsiv.hurriyet.com.tr.

Anadolu Ajansı. Altıncı yüz nakli ameliyatı sona erdi. Radikal Gazetesi. http://www.radikal.com.tr.

Barret, J.P., Serracanta J., Collado J.M., Garrido A., Salamero P., Pont T., et al. (2011). Full face transplantation organization, development, and results-the barcelona experience: a case report. Transplant Proc, 43(9), 3533-34.

Edgar, A. (2009). The challenge of transplants to an intersubjectively established sense of personal identity. Health Care Analysis, 17(2), 123-133. 
Göçmen Baykara, Z., Güler Demir, S., \& Erden, S. (2015). Biomedical ethical evaluation of Turkish newspaper articles on face transplants. International Journal of Human Sciences, 12(1), 427-442. doi: 10.14687/ijhs.v12i1.3076

Elçioğlu, Ö.Ş. (2003). Organ aktarımı ve etik. Erdemir, A.D, Öncel, Ö. \& Aksoy, Ş. (ed). İn: Çağdaş T⿰力丶丶 Etiği. Istanbul (p.309-324). İstanbul: Nobel Tip Kitabevleri Ltd. Şti.

Erdoğan, İ. (2006). Medya ve etik: eleştirel bir giriş. İletişim Kuram ve Araştrrma Dergisi, 23:1-26.

http://iris-interaktif.com/Biyoetik/files/gorusler/TBD_OrganNakli_Raporuus.pdf

International Council_of_Nurses (2012). The ICN Code of Ethics for Nurses. Geneva, ICN.

Kompozit Doku Nakli Endikasyon Listesi (2011). http:/ /www.saglik.gov.tr

Kompozit Doku Nakli Merkezleri Yönergesi. (2011). http://www.saglik.gov.tr.

Medya Derneği (2011). Türkiyeli Gazeteciler İçin Etik İlkeler. İstanbul: Medya Derneği.

Oğuz, Y.N., Tepe, H., Büken, N.Ö. \& Kucur, D,K. (2005). Biyoetik Terimler Söұliügü. Ankara: Meteksan Anonim Şirketi.

Pomahac, B., Nowinski, D., Diaz-Siso, J.R., Bueno, E.M., Talbot, S.G., Sinha, I., et al. (2011). Face transplantation introduction and ethical considerations. Curr Probl Surg, 48(5); 293-357.

Siemionow, M., Bramstedt, K.A., Kodish, E. (2007). Ethical issues in face transplantation. Current Opinion in Organ Transplantation; 12(2), 193-7.

Sterodimas, A., Radwanski, H.N., Pitanguy, I. (2011). Ethical issues in plastic and reconstructive surgery. Aesthetic Plast Surg; 35(2), 262-7.

T.C. Resmi Gazete. (2004). Biyoloji Tibbın Uygulanması Bakımından İnsan Hakları ve İnsan Haysiyetinin Korunması Sözleşmesi: İnsan Hakları ve Biyotıp Sözleşmesi’nin Onaylanması Hakkinda Karar. http:/ /www.resmigazete.gov.tr.

T.C. Sağlık Bakanlığı Türkiye Kamu Hastaneleri Kurumu. (1960). T1bbi Deontoloji Nizamnamesi, Retrieved from http://www.tkhk.gov.tr.

T.C. Sağlık Bakanlığı. (1998). Hasta Hakları Yönetmeliği. http://www.saglik.gov.tr.

THD: Türk Hemşireler Derneği. (2009). Hemşireler için etik ilkeler ve sorumluluklar. Ankara: Türk Hemşireler Derneği.

Türk Tabipler Birliği Merkez Konseyi. (2009). Füsun Sayek TTB Raporlar/Kitaplar- Sağhlkla İlgili Uluslar Arası Belgeler. 2. Baskı. Ankara: Türk Tabipler Birliği Yayınları

Türkiye Biyoetik Derneği. (2012). Türkiye Biyoetik Derneği Organ Nakli ve Etik İlkeler Görüşü. www.biyoetik.org.tr.

Türkiye Organ ve Doku Bağışı Bilgi Sistemi (2013). Kompozit Organ İstatistikleri https://organ.saglik.gov.tr.

Türkiye Organ ve Doku Bilgi Sistemi (2013). Beyin Ölümü İstatistikleri. https:/ /organ.saglik.gov.tr.

Türkiye Organ ve Doku Bilgi Sistemi (2013) Donör İstatistikleri. https://organ.saglik.gov.tr.

Türkiye Organ ve Doku Bilgi Sistemi (2013). Güncel Bekleme Listesi. https://organ.saglik.gov.tr.

Türkiye Organ ve Doku Bilgi Sistemi (2013). Nakil İstatistikleri. https://organ.saglik.gov.tr.

Unal, C. (2013). Beşinci yüz nakli başarılı bir şekilde tamamlandı. Zaman Garetesi. http://www.zaman.com.tr.

Vercler, K.J. (2010). Ethical 1ssues in face transplantation. American Medical Association Journal of Ethics; 12(5): 378-82.

Wong, W.W., Camp, M.C., Camp, J.S., \& Gupta, S.C. (2010). The quality of internet advertising in aesthetic surgery: an in-depth analysis. Aesthetic Sungery Journal; 30(5):735-43. 